\title{
Developing envelope trade-off coefficients using annual energy simulations and multiple linear regressions
}

\author{
Mayank Bhatnagar ${ }^{1}$, Piyush Varma ${ }^{1}$, Hisham Ahmad ${ }^{1}$, Tanmay Tathagat ${ }^{1}$, Sourabh Diddi $^{2}$ \\ ${ }^{1}$ Environmental Design Solutions Pvt. Ltd., New Delhi, India \\ ${ }^{2}$ Bureau of Energy Efficiency, New Delhi, India
}

\begin{abstract}
The Energy Conservation Building Code (ECBC 2017) for India has been updated recently. The code applies to all commercial buildings with a connected load of more than $100 \mathrm{~kW}$ or contract demand of over $120 \mathrm{kVA}$. ECBC 2017 sets the vision for net-zero energy buildings and has stringent requirements for building envelope, lighting and controls, comfort systems and controls, electrical systems and renewable energy integration. The code focuses on design and envelope with stringent requirement of thermal conductance of wall, roof and windows; Solar Heat Gain Coefficient (SHGC) for windows, and mandatory daylighting. ECBC 2017 has prescriptive as well as whole-building compliance alternatives. For ease of compliance, three envelope trade-off options were developed. These include a trade-off between:

1. wall, roof, and window u-factors and SHGC;

2. shading equivalent factor for adjusted SHGC

3. shading and window U-value.
\end{abstract}

The paper presents the analysis approach and final results for envelope trade-off coefficients, using multiple linear regressions; shading equivalent factor coefficients for adjusted SHGC and the trade between window U-value and shading.

\section{Introduction}

Building energy standards or codes are becoming more and more important in energy efficiency policies (Jandat $\&$ Busch, 1994). These standards can help raise concern and awareness of building energy conservation, promote energy efficient designs in buildings, encourage the development of energy efficient products and form a basis for assessing building energy performance and developing energy efficiency programmes (Lam \& Hui, 1996). Internationally, almost every country is now developing or upgrading their building energy codes in order to achieve energy efficiency goals.

The Government of India enacted the Energy Conservation (EC) Act in 2001. One of the main provisions of the EC Act is to develop and implement the Energy Conservation Building Code (ECBC). The first version of ECBC was launched in May 2007. Building Codes and regulations have the potential to improve and standardize construction practices. These, however, require constant revisions and updates to keep current with improvements in technology. In line to upgradation, the ECBC has been updated in the year 2017 with stringent requirements of the envelope, lighting, thermal comfort and system, electrical and renewable energy. The code applies to all commercial buildings with a connected load of more than $100 \mathrm{~kW}$ or contract demand of $120 \mathrm{kVA}$ (Bureau of energy efficiency, 2017).

The code has two compliance options - Prescriptive and Whole Building Performance. The prescriptive method allows simple compliance; however, sometimes it may not be economical or buildable options. For the ease of compliance and to provide more flexibility in the Prescriptive method, the ECBC 2017 provides alternative compliance methods for the trade-off of building parameters without using energy simulation. However, each section (envelope, lighting, HVAC) of ECBC can trade-off in between the parameters of their section. For example, the envelope trade-off is the trade-off inbetween envelope parameters such as wall, roof, and window glazing.

Similar compliance options are available in other international building energy efficiency codes and standards(ASHRAE 90.1-2007, 2007), (Company, 2007).

The code has provided three compliance methods for a different combination of envelope parameters:

1. Trade-off between U-factor of wall, roof, and glass; and glass SHGC

2. Glass SHGC adjustment due to permanent shading devices

3. Glass U-factor adjustment due to permanent shading

This paper presents the methodology and results of different trade-off options of envelope parameters.

\section{Methodology}

\section{Trade-off between wall, roof, and window}

The parameters included in this trade-off option are Ufactors of wall, roof and window; and window SHGC. The representative simulation models were developed on extensive field surveys of the current design, construction, lighting, air-conditioning equipment and operations in the
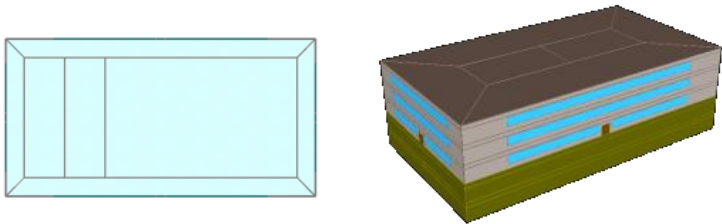

Figure 1: Building footprint and 3D model of the small office building 
country. Sixteen building typologies were modeled for five climate zones using eQUEST (Somani \& Bhatnagar, 2015).

The coefficients of envelope trade-off were determined by parametric runs for the following factors for all four orientation for each climate zone:

1. wall constructions (U-value range: $0.14 \mathrm{~W} / \mathrm{m}^{2} \mathrm{~K}$ to $2.14 \mathrm{~W} / \mathrm{m}^{2} \mathrm{~K}$ ),

2. roof constructions (U-value range $0.2 \mathrm{~W} / \mathrm{m}^{2} \mathrm{~K}$ to $2.2 \mathrm{~W} / \mathrm{m}^{2} \mathrm{~K}$ ) and

3. windows (U-value range $1 \mathrm{~W} / \mathrm{m}^{2} \mathrm{~K}$ to $5 \mathrm{~W} / \mathrm{m}^{2} \mathrm{~K}$ and SHGC range 0.1 to 0.77 )

Multiple linear regressions were used to derive the relationship between one continuous dependent variable (energy consumption per unit area) and two or more independent variables (U-value of wall, roof, and glass with SHGC).

The overall thermal transfer value (OTTV) developed internationally to evaluate the building envelope performance is based on total heat gain from the envelope(Devgan, Jain, \& Bhattacharjee, 2010),(Chirarattananon \& Taveekun, 2004),(Hui, 1997). However, the envelope not only gains heat but also loses to ambient through conduction and radiation. Therefore, the heat gain approach is not appropriate. Additionally, the intent of ECBC is to reduce energy use.

Envelope Performance Factor (EPF) in this study is defined as a measure of energy use due to the external envelope and can be expressed as energy use $(\mathrm{kWh})$ per unit area of the surface $\left(\mathrm{m}^{2}\right)$ over the year. Three components of envelope are considered: (1) energy use due to wall conduction, (2) energy use due to window conduction and radiation and (3) energy use due to roof conduction. As walls and windows at different orientations receive a different amount of solar radiation, consequently, the thermal zones located in each orientation have different energy use. The floor plans for simulation models for each building have perimeter zones presenting four orientations. The method is to first calculate coefficients for each thermal zone representing four orientations for walls, windows, and roof and then condense to single values with low variation.

The envelope performance factor of the building can be calculated using the following equations.

$$
\begin{gathered}
\boldsymbol{E P F}_{\text {Total }}=\boldsymbol{E P F}_{\text {Roof }}+\boldsymbol{E P}_{\boldsymbol{W a l l}_{\text {all }}+\boldsymbol{E P F}_{\text {Fenest }}} \\
E P F_{\text {Roof }}=c_{\text {Roof }} \sum_{s=1}^{n} U_{s} A_{s} \\
E P F_{\text {Wall }}=c_{\text {Wall }} \sum_{s=1}^{n} U_{s} A_{s}
\end{gathered}
$$

$$
\begin{aligned}
& E P F_{\text {Fenest }}=c_{1 \text { Fenest }, \text { North }} \sum_{w=1}^{n} U_{w} A_{w} \\
& +c_{2 \text { Fenest,North }} \sum_{w=1}^{n} \frac{S H G C_{w}}{S E F_{w}} A_{w} \\
& +c_{1 \text { Fenest, South }} \sum_{w=1}^{\substack{w=1 \\
n}} U_{w} A_{w} \\
& +c_{2 \text { Fenest, South }} \sum_{w=1}^{n} \frac{S H G C_{w}}{S E F_{w}} A_{w} \\
& +c_{1 \text { Fenest,East }} \sum_{w=1}^{n^{w=1}} U_{w} A_{w} \\
& +c_{\text {2Fenest,East }} \sum_{w=1}^{n} \frac{S H G C_{w}}{S E F_{w}} A_{w} \\
& +c_{1 \text { Fenest,West }} \sum_{w=1}^{n} U_{w} A_{w} \\
& +c_{2 \text { Fenest,West }} \sum_{w=1}^{n} \frac{S H G C_{w}}{S E F_{w}} A_{w}
\end{aligned}
$$

Values of "c" are coefficients for each class of construction.

$\mathrm{EPF}_{\text {Roof }}$

Envelope performance factor for roofs. Other subscripts include walls and fenestration.

As, Aw The area of a specific envelope component referenced by the subscript "s" or for windows the subscript "w".

SHGC $_{\mathrm{w}} \quad$ The solar heat gain coefficient for windows (w).

$\mathrm{SEF}_{\mathrm{w}} \quad$ A multiplier for the window SHGC that depends on the projection factor of an overhang or side fin.

$\mathrm{U}_{\mathrm{s}} \quad$ The U-factor for the envelope component referenced by the subscript "s".

CRoof A coefficient for the "Roof" class of construction.

$c_{\text {wall }} \quad$ A coefficient for the "Wall"

$c_{1 \text { Fenes }} \quad$ A coefficient for the "Fenestration U-factor"

$\mathrm{c}_{2 \text { Fenes }} \quad$ A coefficient for the "Fenestration SHGC"

\section{Trade-off between window SHGC and shading}

The code does not mandate or prescribed any permanent shading devices. However, it has provisions to adjust SHGC values of window glass for permanent shading devices. The impact of shading is evaluated based on heating and cooling energy use. To analyze the impact of shading, a five-zone model has been created in EnergyPlus. Figure 2 shows the building geometry. The floor plan has been divided into perimeter and core. The geometry of perimeter areas avoids the effect of adjacent perimeter space in a different orientation. The shading impact analysis included the following parametrics:

1. Three types of shading devices
a. Overhang only
b. Fins only
c. Overhangs + fins 
2. Projection factor ranging from 0 to 1 at intervals of 0.25

3. Eight orientations (N, S, E, W, N-E, N-W, S-E, S-W)

4. SHGC ranging from 0.2 to 0.65 at intervals of 0.05

5. 4 Latitudes covering the extent of India

In context of this study, a projection factor is the ratio of the depth of external shading - overhang/fins to farthest side of the window.
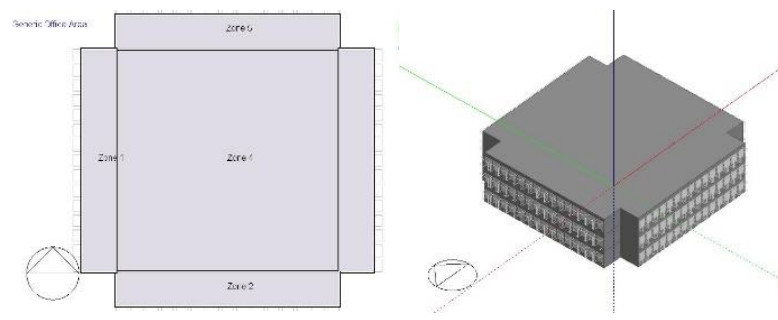

Figure 2: Floor plan and 3D geometry of the building model

The energy use for a thermal zone is varies for different values of SHGC and projection factors. A best fit curve is plotted between SHGC and energy use for each projection factor. The relation between SHGC and energy use for cooling dominated climate is linear. The slope of the line shows the variation in energy use due to SHGC. Considering the slope of line for zero projection factor (i.e. without shading) as baseline, the increment in slope for other Projection Factors has been computed as ratio of coefficients. These ratios serve as SHGC adjustment factors for the trade-off calculations

\section{Trade-off of window $U$-factor with shading}

The code prescribes maximum window assembly Ufactor of $3.3 \mathrm{~W} / \mathrm{m} 2 \mathrm{~K}$ and $0.27 \mathrm{SHGC}$. The U-factor of single glazed units are not able to meet the prescriptive requirement as the $\mathrm{U}$-factor for glass alone ranges from 3.0 to 5.8Additionally, the cost of single glazed to double glazed has a significant cost implication. There is scope for adjustment in SHGC considering the reduction in solar gain attributed to shading devices. Therefore, the energy use reduction due to shading devices can be transferred from the adjustment of SHGC to U-factor to neutralize the energy use taking the same SHGC.

The methodology is the same as defined in shading equivalent factor for adjustment of SHGC except it also includes variation in the $\mathrm{U}$-factor of fenestration. The heating and cooling equivalencies were now established for varying shading projection factors and the U-factor of fenestration.

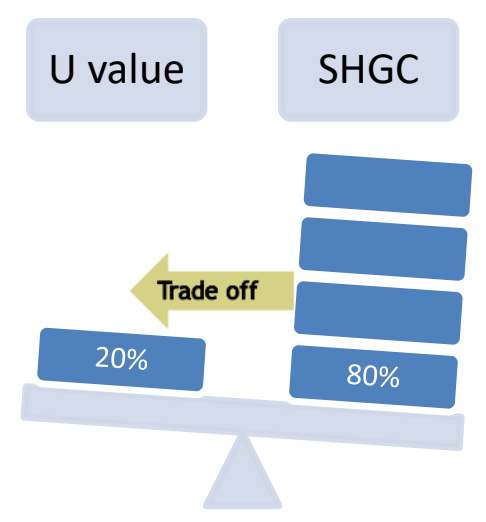

Figure 3: Transferring energy component from SHGC to U-factor

\section{Results and discussion}

\section{Trade-off between wall, roof, and window}

The total 2,646 combinations of parameters specified in the methodology section have been simulated for 16 building types in 5 climate zones of India. The multiple regression analysis has been done for each orientation. For the regression analysis, the parametric values were multiplied by their respective surface area to get heat transfer rate through the surface, e.g. wall U-factor is multiplied by the total wall area for each orientation. The heat transfer rates of wall, roof, and fenestration are considered as independent variables and energy consumption as a dependent variable for multi-variable linear regression analysis. The intercept value has been considered zero to neutralize the effect of internal loads. Table 1 to Table 4 present statistical results for each orientation for composite climate zone.

Table 1: Regression statistics results of North orientation

\begin{tabular}{|l|c|c|c|c|}
\hline & Coefficients & $\begin{array}{c}\text { Standard } \\
\text { Error }\end{array}$ & $\begin{array}{c}\text { t } \\
\text { Stat }\end{array}$ & P-value \\
\hline Intercept & 0 & - & - & - \\
\hline Roof UA & 43.72 & 1.34 & 32.43 & 0.00 \\
\hline Wall UA & 23.26 & 1.03 & 22.57 & 0.00 \\
\hline Glass UA & 21.61 & 0.56 & 37.99 & 0.00 \\
\hline $\begin{array}{l}\text { Glass } \\
\text { SHGCA }\end{array}$ & 201.80 & 3.50 & 57.58 & 0.00 \\
\hline \multicolumn{5}{|c|}{0.97} \\
\hline Multiple R Regression Statistics \\
\hline R Square & \multicolumn{3}{|c|}{0.95} \\
\hline Adjusted R Square & 12124.31 \\
\hline Standard Error & \multicolumn{3}{|c|}{2646} \\
\hline Observations
\end{tabular}


Table 2: Regression statistics results of South orientation

\begin{tabular}{|l|c|c|c|c|}
\hline & Coefficients & $\begin{array}{c}\text { Standard } \\
\text { Error }\end{array}$ & $\begin{array}{c}\mathbf{t} \\
\text { Stat }\end{array}$ & $\begin{array}{c}\text { P- } \\
\text { value }\end{array}$ \\
\hline Intercept & 0 & - & - & - \\
\hline Roof UA & 38.93 & 1.35 & 28.74 & 0.00 \\
\hline Wall UA & 25.38 & 1.04 & 24.50 & 0.00 \\
\hline Glass UA & 19.12 & 0.57 & 33.44 & 0.00 \\
\hline $\begin{array}{l}\text { Glass } \\
\text { SHGCA }\end{array}$ & 342.51 & 3.52 & 97.26 & 0.00 \\
\hline \multicolumn{4}{|c|}{ Regression Statistics } \\
\hline Multiple R & \multicolumn{3}{|c|}{0.98} \\
\hline R Square & \multicolumn{3}{|c|}{0.97} \\
\hline Adjusted R Square & 263.30 \\
\hline Standard Error & \multicolumn{3}{|c|}{} \\
\hline Observations &
\end{tabular}

Table 3: Regression statistics results of East orientation

\begin{tabular}{|l|c|c|c|c|}
\hline & Coefficients & $\begin{array}{c}\text { Standard } \\
\text { Error }\end{array}$ & $\begin{array}{c}\text { t } \\
\text { Stat }\end{array}$ & $\begin{array}{c}\text { P- } \\
\text { value }\end{array}$ \\
\hline Intercept & 0 & - & - & - \\
\hline Roof UA & 39.83 & 1.35 & 29.57 & 0.00 \\
\hline Wall UA & 24.33 & 0.96 & 25.31 & 0.00 \\
\hline Glass UA & 18.76 & 0.53 & 35.29 & 0.00 \\
\hline $\begin{array}{l}\text { Glass } \\
\text { SHGCA }\end{array}$ & 295.63 & 3.27 & 90.28 & 0.00 \\
\hline \multicolumn{4}{|c|}{ Regression Statistics } \\
\hline Multiple R & \multicolumn{3}{|c|}{0.98} \\
\hline R Square & \multicolumn{3}{|c|}{0.96} \\
\hline Adjusted R Square & 6286.24 \\
\hline Standard Error & \multicolumn{3}{|c|}{2646} \\
\hline Observations & \multicolumn{4}{|c|}{} \\
\hline
\end{tabular}

Table 4: Regression statistics results of West orientation

\begin{tabular}{|c|c|c|c|c|}
\hline & Coefficients & $\begin{array}{c}\text { Standard } \\
\text { Error }\end{array}$ & t Stat & $\begin{array}{c}\text { P- } \\
\text { value }\end{array}$ \\
\hline Intercept & 0 & - & - & - \\
\hline Roof UA & 41.02 & 1.35 & 30.40 & 0.00 \\
\hline Wall UA & 24.22 & 0.96 & 25.14 & 0.00 \\
\hline $\begin{array}{l}\text { Glass UA } \\
\text { West }\end{array}$ & 19.25 & 0.53 & 36.13 & 0.00 \\
\hline $\begin{array}{l}\text { Glass } \\
\text { SHGC A }\end{array}$ & 295.43 & 3.28 & 90.04 & 0.00 \\
\hline \multicolumn{5}{|c|}{ Regression Statistics } \\
\hline \multicolumn{2}{|l|}{ Multiple R } & \multicolumn{3}{|c|}{0.98} \\
\hline \multicolumn{2}{|c|}{ R Square } & \multicolumn{3}{|c|}{0.96} \\
\hline \multicolumn{2}{|c|}{ Adjusted R Square } & \multicolumn{3}{|c|}{0.96} \\
\hline \multicolumn{2}{|c|}{ Standard Error } & \multicolumn{3}{|c|}{6298.96} \\
\hline \multicolumn{2}{|c|}{ Observations } & \multicolumn{3}{|c|}{2646} \\
\hline
\end{tabular}

The P-value for each parameter in each orientation is less than 0.05 which indicates that the change in envelope parametric values are related to change in energy consumption of the buildings. The multiple correlation coefficient (Multiple R) is more than 0.9 in each orientation. This indicates that the correlation among the independent variables is positive. The coefficient of determination (R-square) is around 0.97 which means that $97 \%$ of the variation in the dependent variables is explained by the independent variables. The derived coefficients indicate that the glass SHGC has the highest impact on building energy consumption followed by wall, roof and window $\mathrm{U}$-factor. As India is a cooling dominant country, the heat gain through radiation has a higher impact compared to the conductance of wall, roof, and fenestration. The coefficient of the roof is higher compared to the wall and fenestration as the heat gain from the surface is also dependent on surface temperature. The outside surface temperature of the wall or roof will increase above the outside air temperature due to the incident solar radiation and the incident solar radiation on roof always higher than the wall and fenestration due to the incident angle. A similar analysis has been done for 16 building types and summarized for ease of compliance. The set of envelope trade-off coefficients are presented in Table 5 to Table 9 for:

1. each of the five climate zones

2. two different operations- 8-hours and 24-hours

3. U-values for wall and roof;

4. U-value and SHGC for windows in four orientations.

The building envelope complies with the code if the Envelope Performance Factor (EPF) of the Proposed Building, calculated using the equation mentioned in the methodology, is less than the EPF of the Standard Building, where the Standard Building is being calculated with the prescriptive requirements of building envelope as per ECBC 2017. This compliance option is limited to buildings with WWR $<40 \%$ and the thermal property range as mentioned below:

1. wall constructions (U-value range: $0.14 \mathrm{~W} / \mathrm{m}^{2} \mathrm{~K}$ to $\left.2.14 \mathrm{~W} / \mathrm{m}^{2} \mathrm{~K}\right)$,

2. roof constructions (U-value range $0.2 \mathrm{~W} / \mathrm{m}^{2} \mathrm{~K}$ to $\left.2.2 \mathrm{~W} / \mathrm{m}^{2} \mathrm{~K}\right)$ and

3. windows (U-value range $1 \mathrm{~W} / \mathrm{m}^{2} \mathrm{~K}$ to $5 \mathrm{~W} / \mathrm{m}^{2} \mathrm{~K}$ and SHGC range 0.1 to 0.77 )

Table 5: Envelope Performance Factor Coefficients Composite Climate

\begin{tabular}{|l|c|c|c|c|}
\hline & \multicolumn{2}{|c|}{$\begin{array}{c}\text { Daytime Business, } \\
\text { Educational, } \\
\text { Shopping Complex }\end{array}$} & \multicolumn{2}{c|}{$\begin{array}{c}\text { 24-hour Business, } \\
\text { Hospitality, Health } \\
\text { Care, Assembly }\end{array}$} \\
\hline & $\begin{array}{c}\text { C factor } \\
\text { U-factor }\end{array}$ & $\begin{array}{c}\text { C factor } \\
\text { SHGC }\end{array}$ & $\begin{array}{c}\text { C factor } \\
\text { U-factor }\end{array}$ & $\begin{array}{c}\text { C factor } \\
\text { SHGC }\end{array}$ \\
\hline Walls & 24.3 & - & 48.1 & - \\
\hline Roofs & 40.9 & - & 71.0 & - \\
\hline $\begin{array}{l}\text { North } \\
\text { Windows }\end{array}$ & 21.6 & 201.8 & 41.0 & 367.6 \\
\hline $\begin{array}{l}\text { South } \\
\text { Windows }\end{array}$ & 19.1 & 342.5 & 41.0 & 546.3 \\
\hline $\begin{array}{l}\text { East } \\
\text { Windows }\end{array}$ & 18.8 & 295.6 & 38.4 & 492.2 \\
\hline $\begin{array}{l}\text { West } \\
\text { Windows }\end{array}$ & 19.2 & 295.4 & 38.3 & 486.1 \\
\hline
\end{tabular}


Table 6: Envelope Performance Factor Coefficients - Hot and Dry Climate

\begin{tabular}{|l|c|c|c|c|}
\hline & \multicolumn{2}{|c|}{$\begin{array}{c}\text { Daytime Business, } \\
\text { Educational, } \\
\text { Shopping Complex }\end{array}$} & \multicolumn{2}{c|}{$\begin{array}{c}\text { 24-hour Business, } \\
\text { Hospitality, Health } \\
\text { Care, Assembly }\end{array}$} \\
\hline & $\begin{array}{c}\text { C factor } \\
\text { U-factor }\end{array}$ & $\begin{array}{c}\text { C factor } \\
\text { SHGC }\end{array}$ & $\begin{array}{c}\text { C factor } \\
\text { U-factor }\end{array}$ & $\begin{array}{c}\text { C factor } \\
\text { SHGC }\end{array}$ \\
\hline Walls & 27.3 & - & 55.9 & - \\
\hline Roofs & 43.9 & - & 80.7 & - \\
\hline $\begin{array}{l}\text { North } \\
\text { Windows }\end{array}$ & 23.7 & 238.2 & 49.1 & 414.4 \\
\hline $\begin{array}{l}\text { South } \\
\text { Windows }\end{array}$ & 22.8 & 389.7 & 49.2 & 607.4 \\
\hline $\begin{array}{l}\text { East } \\
\text { Windows }\end{array}$ & 21.6 & 347.4 & 46.2 & 556.2 \\
\hline $\begin{array}{l}\text { West } \\
\text { Windows }\end{array}$ & 21.7 & 354.1 & 46.0 & 560.8 \\
\hline
\end{tabular}

Table 7: Envelope Performance Factor Coefficients Warm and Humid Climate

\begin{tabular}{|l|c|c|c|c|}
\hline & \multicolumn{2}{|c|}{$\begin{array}{c}\text { Daytime Business, } \\
\text { Educational, } \\
\text { Shopping Complex }\end{array}$} & \multicolumn{2}{c|}{$\begin{array}{c}\text { 24-hour Business, } \\
\text { Hospitality, Health } \\
\text { Care, Assembly }\end{array}$} \\
\hline & $\begin{array}{c}\text { C factor } \\
\text { U-factor }\end{array}$ & $\begin{array}{c}\text { C factor } \\
\text { SHGC }\end{array}$ & $\begin{array}{c}\text { C factor U- } \\
\text { factor }\end{array}$ & $\begin{array}{c}\text { C factor } \\
\text { SHGC }\end{array}$ \\
\hline Walls & 24.5 & - & 51.2 & - \\
\hline Roofs & 40.1 & - & 76.1 & - \\
\hline $\begin{array}{l}\text { North } \\
\text { Windows }\end{array}$ & 20.7 & 230.7 & 43.6 & 401.5 \\
\hline $\begin{array}{l}\text { South } \\
\text { Windows }\end{array}$ & 20.1 & 347.1 & 43.9 & 546.4 \\
\hline $\begin{array}{l}\text { East } \\
\text { Windows }\end{array}$ & 19.0 & 301.8 & 41.1 & 490.6 \\
\hline $\begin{array}{l}\text { West } \\
\text { Windows }\end{array}$ & 18.7 & 303.1 & 40.5 & 483.5 \\
\hline
\end{tabular}

Table 8: Envelope Performance Factor Coefficients Temperate Climate

\begin{tabular}{|l|c|c|c|c|}
\hline & \multicolumn{2}{|c|}{$\begin{array}{c}\text { Daytime Business, } \\
\text { Educational, } \\
\text { Shopping Complex }\end{array}$} & \multicolumn{2}{c|}{$\begin{array}{c}\text { 24-hour Business, } \\
\text { Hospitality, Health } \\
\text { Care, Assembly }\end{array}$} \\
\hline & $\begin{array}{c}\text { C factor } \\
\text { U-factor }\end{array}$ & $\begin{array}{c}\text { C factor } \\
\text { SHGC }\end{array}$ & $\begin{array}{c}\text { C factor } \\
\text { U-factor }\end{array}$ & $\begin{array}{c}\text { C factor } \\
\text { SHGC }\end{array}$ \\
\hline Walls & 17.2 & - & 39.1 & - \\
\hline Roofs & 32.3 & - & 76.1 & - \\
\hline $\begin{array}{l}\text { North } \\
\text { Windows }\end{array}$ & 12.6 & 201.4 & 32.3 & 338.41 \\
\hline $\begin{array}{l}\text { South } \\
\text { Windows }\end{array}$ & 11.8 & 287.3 & 31.9 & 448.52 \\
\hline $\begin{array}{l}\text { East } \\
\text { Windows }\end{array}$ & 11.2 & 300.0 & 29.9 & 470.35 \\
\hline $\begin{array}{l}\text { West } \\
\text { Windows }\end{array}$ & 10.9 & 303.4 & 30.0 & 462.64 \\
\hline
\end{tabular}

Table 9: Envelope Performance Factor Coefficients Cold Climate

\begin{tabular}{|l|c|c|c|c|}
\hline & \multicolumn{2}{|c|}{$\begin{array}{c}\text { Daytime Business, } \\
\text { Educational, } \\
\text { Shopping Complex }\end{array}$} & \multicolumn{2}{c|}{$\begin{array}{c}\text { 24-hour Business, } \\
\text { Hospitality, Health } \\
\text { Care, Assembly }\end{array}$} \\
\hline & $\begin{array}{c}\text { C factor } \\
\text { U-factor }\end{array}$ & $\begin{array}{c}\text { C factor } \\
\text { SHGC }\end{array}$ & $\begin{array}{c}\text { C factor } \\
\text { U-factor }\end{array}$ & $\begin{array}{c}\text { C factor } \\
\text { SHGC }\end{array}$ \\
\hline Walls & 36.3 & - & 30.7 & - \\
\hline Roofs & 38.7 & - & 46.0 & - \\
\hline $\begin{array}{l}\text { North } \\
\text { Windows }\end{array}$ & 21.8 & 137.6 & 28.3 & 163.86 \\
\hline $\begin{array}{l}\text { South } \\
\text { Windows }\end{array}$ & 20.8 & 114.3 & 21.7 & 295.24 \\
\hline $\begin{array}{l}\text { East } \\
\text { Windows }\end{array}$ & 22.7 & 127.5 & 24.1 & 283.20 \\
\hline $\begin{array}{l}\text { West } \\
\text { Windows }\end{array}$ & 23.4 & 133.2 & 25.2 & 270.33 \\
\hline
\end{tabular}

\section{Trade-off between window SHGC and shading}

Based on the simulation results for various combinations in Delhi (Latitude $28.7^{\circ} \mathrm{N}$ ) and Chennai (latitude $13.08^{\circ}$ $\mathrm{N}$ ), graphs were plotted to understand the variation of shading equivalent factor versus projection factor for overhangs, fins, and box frame.

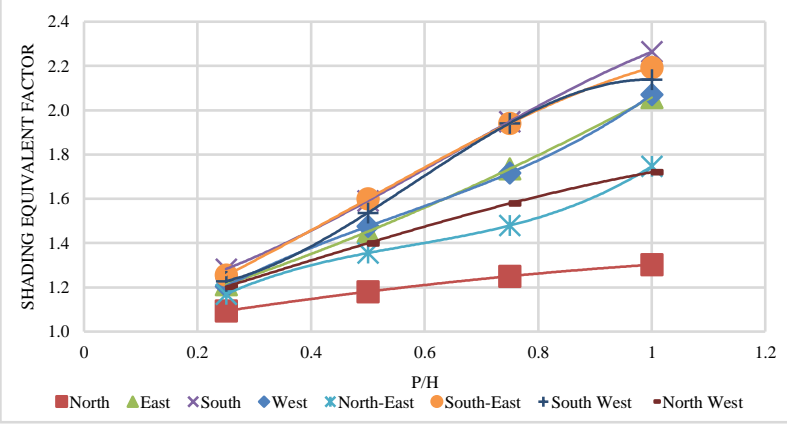

Figure 4: Shading equivalent factor for different projection factor of Overhangs shading for Delhi

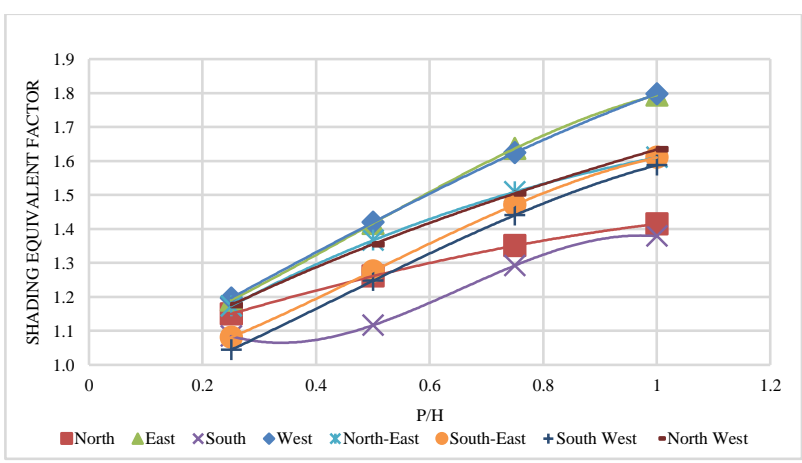

Figure 5: Shading equivalent factor for different projection factor of Overhangs shading for Chennai

Figure 4 for overhangs and box frame in Delhi, the slope of the curve for north orientation is the least and the slope 
of the equation for south orientation is the highest. Figure 5 for overhangs and box frame in Chennai, the impact of overhangs is less in south orientation because of higher sun angles. Moreover, all mirror image cardinal directions, except for the north and south, like east-west, northeast- northwest, and southeast-southwest, have approximately similar trends.

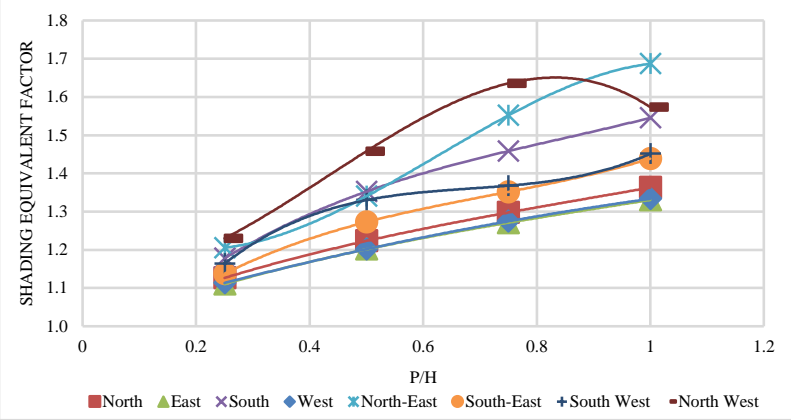

Figure 6: Shading equivalent factor for different projection factor of fins shading for Delhi

For fins in both Delhi and Chennai, the highest impact is observed in the northeast and northwest and the least impact is observed in the north direction. Since the fins are not inclined, the impact on the east-west direction needs to be ignored.

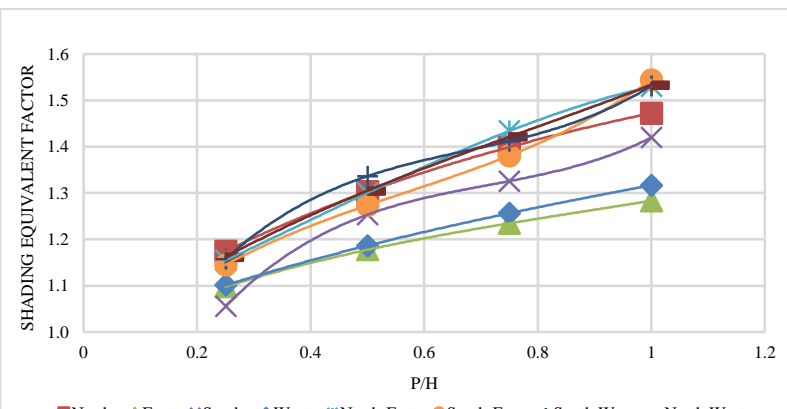

North $\triangle$ East $\times$ South $\bullet$ West $\mathbb{*}$ North-East $\bullet$ South-East $\quad$ +South West $\bullet$ North Wes

Figure 7: Shading equivalent factor for different projection factor of fins shading for Chennai

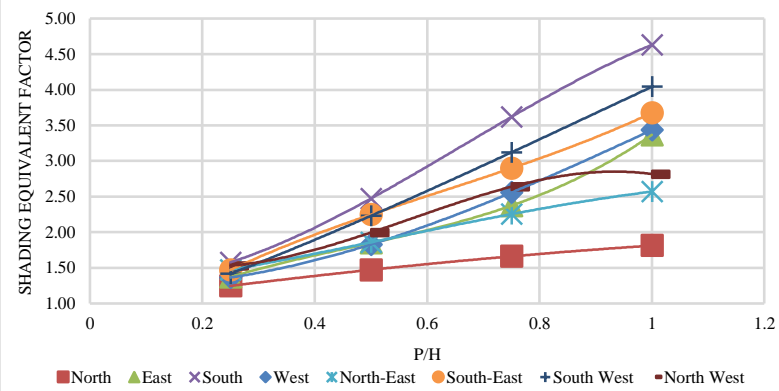

Figure 8 Shading equivalent factor for different projection factor of Overhangs + fins shading for Delhi

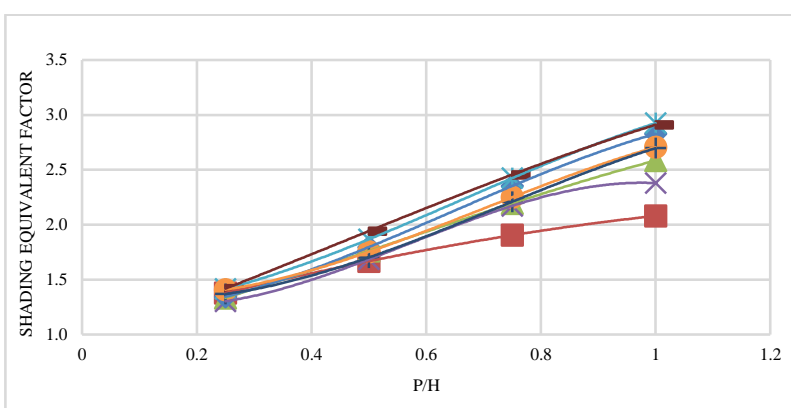

North $\triangle$ East $\times$ South $\bullet$ West $\%$ North-East South-East + South West $\quad$-North West

Figure 9: Shading equivalent factor for different projection factor of Overhangs + fins shading for Chennai

For all three types of shading combinations, the polynomial curve has been fitted for each orientation for Delhi and Chennai. A similar analysis was done for other latitudes with different climate zones.

The equation for Shading Equivalent Factor (SEF) is:

$$
\boldsymbol{S E F}=\left(C_{3} \times P F^{3}\right)+\left(C_{2} \times P F^{2}\right)+\left(C_{1} \times P F\right)+C_{0}
$$

Where,

$\mathrm{C} 3, \mathrm{C} 2, \mathrm{C} 1$, and $\mathrm{C} 0$ are the coefficient of shading equivalent factor (SEF). Appendix 2 list the consolidated coefficients of SEF for latitude more than $15^{\circ} \mathrm{N}$ and less than $15^{\circ} \mathrm{N}$. An equivalent SHGC is calculated by multiplying the SHGC of the unshaded fenestration product with a Shading Equivalent Factor (SEF).

Table 10: Coefficients of Shading Equivalent Factors for Latitudes greater than or equal to $15^{\circ} \mathrm{N}$

\begin{tabular}{|c|c|c|c|c|c|c|c|c|c|c|c|c|}
\hline \multirow[b]{2}{*}{ Coefficients } & \multicolumn{4}{|c|}{ Overhang + Fin } & \multicolumn{4}{|c|}{ Overhang } & \multicolumn{4}{|c|}{ Fin } \\
\hline & $\mathrm{C} 3$ & $\mathrm{C} 2$ & $\mathrm{C} 1$ & $\mathrm{C} 0$ & $\mathrm{C} 3$ & $\mathrm{C} 2$ & $\mathrm{C} 1$ & $\mathrm{CO}$ & $\mathrm{C} 3$ & $\mathrm{C} 2$ & $\mathrm{C} 1$ & $\mathrm{C} 0$ \\
\hline North & -0.03 & -0.23 & 1.09 & 0.99 & -0.02 & -0.10 & 0.43 & 0.99 & 0.14 & -0.39 & 0.62 & 0.99 \\
\hline East & 4.49 & -6.35 & 4.70 & 0.52 & -0.05 & 0.42 & 0.66 & 1.02 & 0.12 & -0.35 & 0.57 & 0.99 \\
\hline South & -4.09 & 8.14 & -0.73 & 1.32 & -1.01 & 1.91 & 0.24 & 1.12 & 0.53 & -1.35 & 1.48 & 0.88 \\
\hline West & -1.21 & 3.92 & -0.56 & 1.28 & 1.52 & -2.51 & 2.30 & 0.76 & 0.02 & -0.15 & 0.46 & 1.01 \\
\hline North-East & -0.95 & 1.50 & 0.84 & 1.18 & 2.19 & -3.78 & 2.62 & 0.72 & -1.64 & 3.07 & -1.05 & 1.30 \\
\hline South-East & 2.67 & -4.99 & 5.68 & 0.32 & -0.93 & 1.37 & 0.76 & 0.99 & 0.68 & -1.47 & 1.35 & 0.88 \\
\hline South-West & -0.50 & 1.36 & 2.45 & 0.73 & -3.23 & 5.61 & -1.56 & 1.32 & 1.86 & -3.81 & 2.71 & 0.69 \\
\hline North-West & -6.85 & 11.7 & -3.92 & 1.89 & -0.22 & 0.19 & 0.74 & 1.01 & -2.02 & 2.63 & -0.18 & 1.14 \\
\hline
\end{tabular}


Table 11: Coefficients of Shading Equivalent Factors for Latitudes less than $15^{\circ} \mathrm{N}$

\begin{tabular}{|c|c|c|c|c|c|c|c|c|c|c|c|c|}
\hline & \multicolumn{3}{|c|}{ Overhang + Fin } & \multicolumn{3}{c|}{ Overhang } & \multicolumn{4}{c|}{ Fin } \\
\hline Coefficients & C3 & C2 & C1 & C0 & C3 & C2 & C1 & C0 & C3 & C2 & C1 & C0 \\
\hline North & -0.09 & -0.29 & 1.41 & 1.05 & -0.05 & -0.10 & 0.54 & 1.02 & 0.10 & -0.40 & 0.77 & 1.01 \\
\hline East & -0.55 & 0.89 & 1.28 & 0.97 & -0.62 & 0.88 & 0.51 & 1.02 & 0.15 & -0.41 & 0.56 & 0.98 \\
\hline South & -4.09 & 6.98 & -1.92 & 1.41 & -2.49 & 4.89 & -2.45 & 1.43 & 1.57 & -3.35 & 2.62 & 0.59 \\
\hline West & -1.99 & 3.82 & -0.19 & 1.18 & -0.16 & 0.10 & 0.89 & 0.97 & 0.06 & -0.22 & 0.48 & 0.99 \\
\hline North-East & -1.73 & 3.45 & -0.02 & 1.23 & 0.10 & -0.55 & 1.15 & 0.92 & -0.26 & 0.30 & 0.48 & 1.02 \\
\hline South-East & -2.06 & 4.32 & -0.96 & 1.41 & -0.60 & 0.90 & 0.37 & 0.94 & 0.83 & -1.42 & 1.22 & 0.92 \\
\hline South-West & -2.06 & 4.48 & -1.13 & 1.40 & -0.39 & 0.50 & 0.60 & 0.87 & 1.56 & -3.17 & 2.41 & 0.73 \\
\hline North-West & -0.53 & 0.72 & 1.79 & 0.93 & 0.10 & -0.38 & 0.96 & 0.96 & 0.24 & -0.57 & 0.90 & 0.97 \\
\hline
\end{tabular}

The restriction on the calculated shading equivalence is that the resultant SHGC should be less than or equal to 1 .

\section{Trade-off between window $\mathrm{U}$-factor and shading}

Figure 10 shows the thermal energy use of a building with a U-factor of $3.3 \mathrm{~W} / \mathrm{m}^{2} \mathrm{~K}$ and $5.0 \mathrm{~W} / \mathrm{m}^{2} \mathrm{~K}$ for different SHGCs. Point A of higher U-factor with low SHGC is equivalent to point B of low U-factor with high SHGC. Similarly, the energy use reduced due to the inclusion of shading devices can be comparable to a higher U-factor. Here, the SHGC will remain constant and the variation of U-factor has been analyzed.

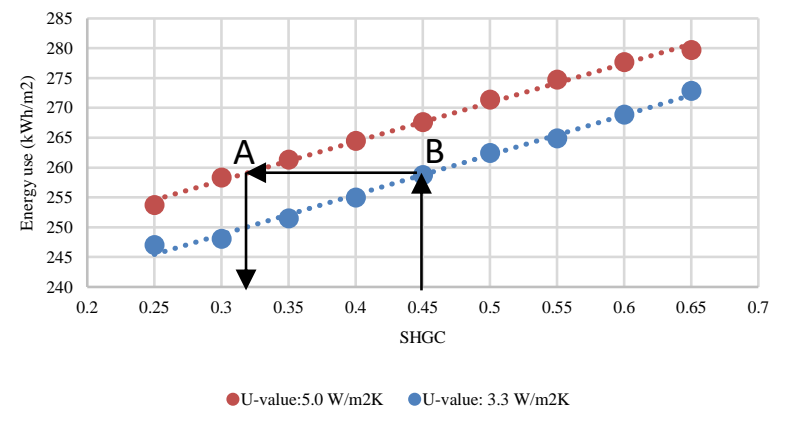

Figure 10: Comparison of energy use of $3.3 \mathrm{~W} / \mathrm{m}^{2} \mathrm{~K}$ and 5.0 $\mathrm{W} / \mathrm{m}^{2} \mathrm{~K}$ for different SHGCS

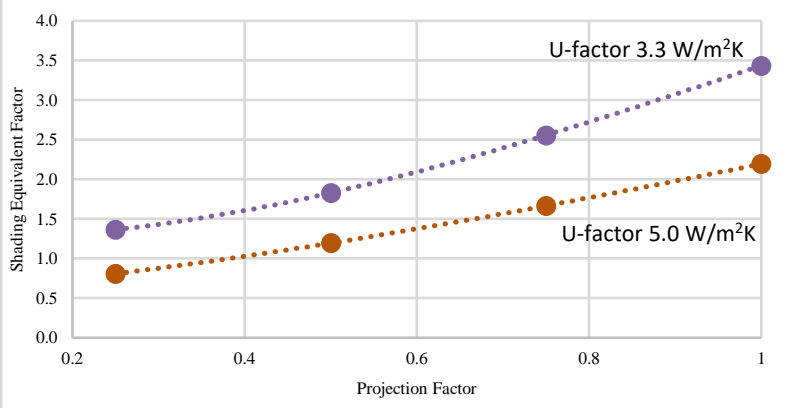

Figure 11: Shading equivalent factor for different projection factor of $3.3 \mathrm{~W} / \mathrm{m}^{2} \mathrm{~K}$ and $5.0 \mathrm{~W} / \mathrm{m}^{2} \mathrm{~K}$
Figure 11 shows the shading equivalent factor with different projection factors for U-factor $5 \mathrm{~W} / \mathrm{m}^{2} \mathrm{~K}$ and 3.3 $\mathrm{W} / \mathrm{m}^{2} \mathrm{~K}$. The $\mathrm{U}$-factor $3.3 \mathrm{~W} / \mathrm{m}^{2} \mathrm{~K}$ is the code's maximum requirement. The shading equivalent factor is 1.0 for the projection factor of 0.4 for U-factor of $5.0 \mathrm{~W} / \mathrm{m}^{2} \mathrm{~K}$ which means the U-factor of $3.3 \mathrm{~W} / \mathrm{m}^{2} \mathrm{~K}$ and 0.27 SHGC will have the same energy use at 0.4 projection factor and $\mathrm{U}$ factor of $5.0 \mathrm{~W} / \mathrm{m}^{2} \mathrm{~K}$ with $0.27 \mathrm{SHGC}$.

Hence, the trade-off has been provided for daytime use buildings to have a higher U-factor at 0.27 SHGC if the building has a shading projection factor of 0.4 or more. The requirement is for all climate zones of India except cold because the impact of the U-factor is more in cold climate zones.

Table 12: Trade-off between window U-value and Shading

\begin{tabular}{|c|c|c|c|}
\hline $\begin{array}{c}\text { Building } \\
\text { Type }\end{array}$ & $\begin{array}{c}\text { Climate } \\
\text { Zone }\end{array}$ & SHGC & $\begin{array}{c}\mathbf{U} \text { value }\left(\mathbf{W} / \mathbf{m}^{2} \mathbf{K}\right) \\
\text { for Shading } \mathbf{P F} \geq \\
\mathbf{0 . 4}\end{array}$ \\
\hline $\begin{array}{c}\text { Day time } \\
\text { buildings }\end{array}$ & $\begin{array}{c}\text { All except } \\
\text { cold climate }\end{array}$ & 0.27 & 5.0 \\
\hline
\end{tabular}

\section{Conclusion}

ECBC 2017 has been updated in the year 2017 with stringent requirements of the envelope. To provide alternative compliance options to the prescriptive path for envelope parameters, the trade-offs between different parameters have been provided. The paper presented the methodology and results of three different trade-off options. The trade-off between wall, roof, and window provides higher flexibility than other trade-off methods. The annual energy consumption emerged as the most appropriate factor for trade-off since the primary objective of ECBC 2017 is to minimize building energy use. The R-square values for all climate zones and different building operations are more than 0.9 , indicating a strong correlation between the envelope parameters and annual energy use.

The coefficients for shading equivalent factors were also determined by analyzing windows with three types of shadings with different projection factors for eight orientation in four different locations by latitudes. The shading equivalent factors were then used to demonstrate prescriptive compliance for window SHGC by factoring in the effect of shading. The shading equivalent factors 
were developed to trade-off the effect of shading on window SHGC for two different latitudes (less than and greater than $15^{\circ} \mathrm{N}$ ), and eight orientations. Similarly, a trade-off between window U-value and shading was developed based on building energy consumption impact with shading.

These trade-offs help to building owner/ developer to meet the code requirement with the prescriptive method to avoid complexity and cost for building energy simulation method. It has also helped to reduce the overall cost of the project and maintaining the intent of the code to minimize the building energy use.

\section{Acknowledgment}

We would like this opportunity to thank entire technical team of Environmental Design Solutions Pvt. Ltd. New Delhi and Bureau of Energy Efficiency, Government of India for their continuous support in development of ECBC 2017

\section{References}

ASHRAE 90.1-2007. ASHRAE STANDARD Energy Standard for Buildings Except Low-Rise Residential Buildings (2007).

Bureau of energy efficiency. Energy Conservation Building Code 2017 (2017). Bureau of energy efficiency. Retrieved from https://beeindia.gov.in/sites/default/files/tender_do cument/BEE_ECBC 2017.pdf

Chirarattananon, S., \& Taveekun, J. (2004). An OTTVbased energy estimation model for commercial buildings in Thailand. Energy and Buildings, 36(7), 680-689. https://doi.org/10.1016/j.enbuild.2004.01.035

Company, P. G. and E. 2008 California Energy Commission Title 24 Building Energy Efficiency Standards - Building Envelope Tradeoff Method (2007).

Devgan, S., Jain, A. K., \& Bhattacharjee, B. (2010). Predetermined overall thermal transfer value coefficients for Composite, Hot-Dry and WarmHumid climates. Energy and Buildings, 42(10), 1841-1861. https://doi.org/10.1016/j.enbuild.2010.05.021

Hui, S. C. M. (1997). Overall Thermal Transfer Value (OTTV): How to Improve Its Control in Hong Kong. Proceedings of the One-Day Symposium on Building, Energy and Environment, (October), 121-11. Retrieved from http://web.hku.hk/ cmhui/bse97a.pdf

Jandat, K. B., \& Busch, J. F. (1994). WORLDWIDE STATUS OF ENERGY STANDARDS FOR BUILDINGS. Elsevier Science Ltd., 19(1), 27-44. Retrieved from https://www.eci.ox.ac.uk/research/energy/downloa ds/janda04-wsesb.pdf

Lam, J. C., \& Hui, S. C. M. (1996). A review of building energy standards and implications for Hong Kong. Building Research \& Information, 24(3), 131-140. https://doi.org/10.1080/09613219608727516

Somani, G., \& Bhatnagar, M. (2015). Stringency analysis of building envelope energy conservation measures in 5 climatic zones of India. Building simulation 2015 (pp. 751-758). 